\title{
Climate Variability Impact on the Spatiotemporal Characteristics of Drought and Aridity in Arid and Semi-Arid Regions
}

\author{
Ruqayah Mohammed ${ }^{1,2} \cdot$ Miklas Scholz $^{2,3,4}$ (D) \\ Received: 9 July 2019 / Accepted: 21 October 2019/ \\ Published online: 4 December 2019 \\ (C) The Author(s) 2019
}

\begin{abstract}
Investigating the spatiotemporal distribution of climate data and their impact on the allocation of the regional aridity and meteorological drought, particularly in semi-arid and arid climate, it is critical to evaluate the climate variability effect and propose sufficient adaptation strategies. The coefficient of variation, precipitation concentration index and anomaly index were used to evaluate the climate variability, while the MannKendall and Sen's slope were applied for trend analysis, together with homogeneity tests. The aridity was evaluated using the alpha form of the reconnaissance drought index (Mohammed \& Scholz, Water Resour Manag 31(1):531-538, 2017c), whereas drought episodes were predicted by applying three of the commonly used meteorological drought indices, which are the standardised reconnaissance drought index, standardized precipitation index and standardized precipitation evapotranspiration index. The Upper Zab River Basin (UZRB), which is located in the northern part of Iraq and covers a high range of climate variability, has been considered as an illustrative basin for arid and semiarid climatic conditions. There were general increasing trends in average temperature and potential evapotranspiration and decreasing trends in precipitation from the upstream to the downstream of the UZRB. The long-term analysis of climate data indicates that the number of dry years has temporally risen and the basin has experienced succeeding years of drought, particularly after 1994/1995. There was a potential link between drought, aridity and climate variability. Pettitt's, SNHT, Buishand's and von Neumann's homogeneity test results demonstrated that there is an evident alteration in the mean of the drought and aridity between the pre- and post-alteration point (1994).
\end{abstract}

Keywords Aridity index $\cdot$ Climate data variability $\cdot$ Climatic drought $\cdot$ Multi-scalar drought index . Trend analysis $\cdot$ Homogeneity analysis

Electronic supplementary material The online version of this article (https://doi.org/10.1007/s11269-01902397-3) contains supplementary material, which is available to authorized users.

Miklas Scholz

miklas.scholz@tvrl.lth.se

Extended author information available on the last page of the article 


\section{Introduction}

Research on long-term variations in meteorological data is important to identify climate change and variability as well as human-induced water resources management impacts (Mohammed and Scholz 2017b, 2018; Yue et al. 2018). Due to climate change impact and anthropogenic intervention, temporal and areal meteorological parameters would mostly vary in the long-term and cause alterations in the local and global hydrological cycle. Climate change and climate variability are anticipated to influence land use, land cover, water resources and ecological sustainability. Extreme hydro-climatic events such as floods and droughts can be considered the most important impacts of such changes (Michel and Pandya 2009; Mittal et al. 2016). Consequently, it would be useful to evaluate the hydrological process responses to such alteration to enhance decision makers understanding for the hydrological processes and to improve sustainable water resources management strategies.

Precipitation and temperature are key parameters to describe the climate over all scales (from local to global). Analysing the long-term trend of these parameters at a basin scale is useful for the assessment of the regional environment. The evapotranspiration variable is usually involved in water balance research. Accordingly, it can be considered as a more expressive variable for substituting temperature in water resources management (Mohammed and Scholz 2017a). Analysis of long time series concerning temperature, precipitation and potential evapotranspiration for an area may produce one of the following collections: $+++,++0,++-,+0+,+00,+0-,+-+,+-0,+--,-++,-+0,-+$ $-,-0+,-00,-0-,--+,--0,---$, where,+- and 0 represents a rise, a decline, and no change, respectively.

Many researchers have recently carried out extensive studies on trend analysis of climatic parameters such as precipitation (Koutroulis et al., 2011; Beguería et al. 2014; Khan et al. 2016; Ahmad et al. 2018; Asfaw et al. 2018), air temperature, meteorological drought (Banimahd and Khalili 2013; Trenberth et al. 2014; Moral et al. 2016; Deng et al., 2017; Cheng et al. 2018; Hazbavi et al. 2018; Yue et al. 2018) and regional aridity (Hrnjak et al. 2014; Djebou 2017; Mohammed and Scholz 2017a; Radaković et al. 2018). However, most research has focused on the spatiotemporal distribution of drought, examined potential drought patterns based on results from global and/or regional climate models (Koutroulis et al., 2011; Trenberth et al. 2014; Asfaw et al. 2018) and investigated the spatial and temporal variation of drought and aridity (Banimahd and Khalili 2013; Liu et al. 2015; Moral et al. 2016; Deng et al., 2017; Beguería et al. 2014) without evaluation of the potential impact of long-term variations and distributions of weather data on the drought and/or aridity at local scale For example, Tabari et al. (2012) investigated the rainfall and drought severity without linking it to the variation of the weather regional aridity.

Accordingly, this research aims to assess the impact of long-term variations and distributions of meteorological data on the regional drought and aridity during the last 35 years (19792014) considering the UZRB as an illustrative basin example to represent arid and semi-arid climatic conditions. The corresponding objectives are to (a) examine the spatial distributions and temporal variations at monthly and annual time scales of climate variables (Fig. 1 and Table 1); (b) evaluate the impact of potential evapotranspiration to the variations of mean air temperature; (c) evaluate the potential impact of climate varability on aridity and drought; (d) assess the relationship between drought and aridity; and (e) predict the long-term temporal variations of both drought and aridity. Figure 2 shows how the study objectives can be linked to eachother to achieve the main research aim. 


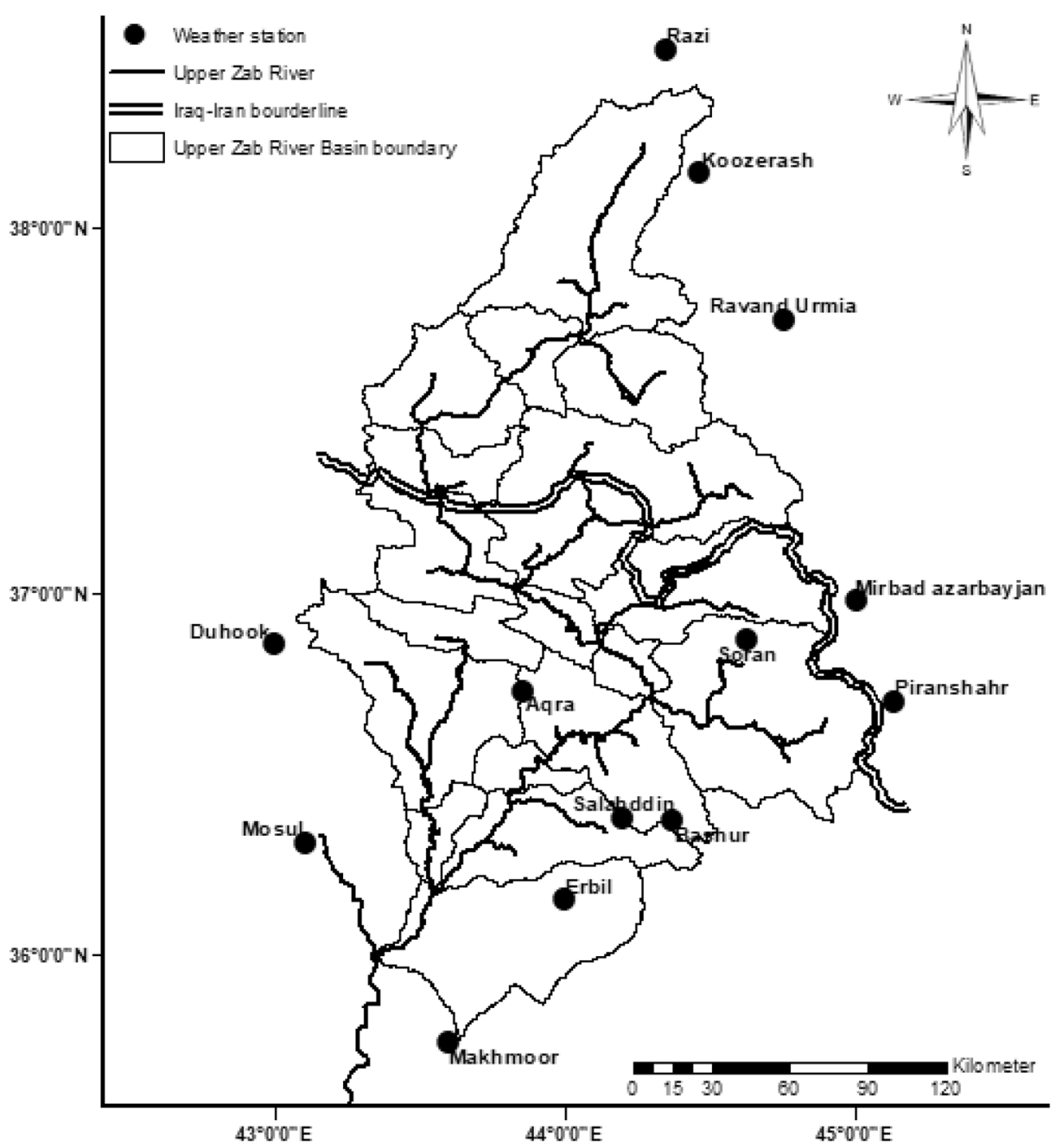

Fig. 1 Meteorological stations locations in the Upper Zab River Basin

This research can be seen as a comperhensive study during which the relationship between climate variables, drought events and aridity are assessed at a local scale. This in turn can help to understand to what extent such relationship would affect basin hydrology in arid regions.

\section{Data and Methodology}

\subsection{Illustrative Case Study Region}

The Upper Zab River (UZR) is one the largest tributaries of the Tigris River in terms of water yield. The river has its spring in Turkey, runs through the northern part of Iraq, and subsequently joins the Tigris River covering a distance of about $372 \mathrm{~km}$ (Fig. 1). The UZR and its tributaries are located between latitudes $36^{\circ} \mathrm{N}$ and $38^{\circ} \mathrm{N}$, and longitudes $43.3^{\circ} \mathrm{E}$ and $44.3^{\circ} \mathrm{E}$. The UZRB covers an area of 
Table 1 Station addresses with corresponding aridity index $\left(\mathrm{RDI}_{\alpha 12}\right)$ range and long-term average meteorological variables computed by the Thiessen network and the sub-area sizes

\begin{tabular}{|c|c|c|c|c|c|c|c|c|c|c|}
\hline \multicolumn{2}{|c|}{ Station } & \multirow{2}{*}{$\begin{array}{l}\text { Lat }^{\mathrm{a}} \\
\left({ }^{\circ}\right)\end{array}$} & \multirow{2}{*}{$\begin{array}{l}\text { Long } b \\
\left(^{\circ}\right)\end{array}$} & \multirow{2}{*}{$\begin{array}{l}\text { Altitc } \\
(\mathrm{m})\end{array}$} & \multicolumn{2}{|c|}{ Ariditylimits } & \multirow[t]{2}{*}{$\mathrm{a}_{\mathrm{i}}^{\mathrm{d}}\left(\mathrm{km}^{2}\right)$} & \multicolumn{3}{|c|}{ Average } \\
\hline No & ID & & & & Upper & Lower & & $\begin{array}{l}\mathrm{T}_{\mathrm{m}} \mathrm{e} \\
\left({ }^{\circ} \mathrm{C}\right)\end{array}$ & $\mathrm{P}^{\mathrm{f}}(\mathrm{mm})$ & $\begin{array}{l}\text { PETg }^{\mathrm{g}} \\
(\mathrm{mm})\end{array}$ \\
\hline 1 & Razi & 38.48 & 44.35 & 1980 & $1.43^{5}$ & $0.35^{2}$ & 638.512 & 5.36 & 661.53 & 860.18 \\
\hline 2 & Koozerash & 38.15 & 44.46 & 1344 & $1.20^{5}$ & $0.38^{2}$ & 5703.939 & 5.18 & 754.73 & 912.79 \\
\hline 3 & Ravand Urmia & 37.75 & 44.76 & 1290 & $0.73^{5}$ & $0.26^{2}$ & 2340.584 & 7.70 & 495.90 & 1008.03 \\
\hline 4 & $\begin{array}{l}\text { Mirbad } \\
\text { Azarbayjan }\end{array}$ & 36.98 & 45.01 & 1650 & $1.44^{5}$ & $0.48^{2}$ & 433.351 & 8.82 & 1099.06 & 1103.28 \\
\hline 5 & Soran & 36.87 & 44.63 & 1132 & $0.95^{5}$ & $0.34^{2}$ & 6712.594 & 9.76 & 812.22 & 1192.39 \\
\hline 6 & Duhook & 36.86 & 43.00 & 276 & $0.98^{5}$ & $0.25^{2}$ & 1325.940 & 16.57 & 844.86 & 1275.51 \\
\hline 7 & Aqra & 36.73 & 43.86 & 555 & $0.57^{4}$ & $0.21^{2}$ & $12,049.926$ & 19.54 & 844.86 & 1529.02 \\
\hline 8 & Piranshahr & 36.70 & 45.13 & 1350 & $0.63^{4}$ & $0.20^{2}$ & 1096.630 & 12.25 & 1107.69 & 1309.73 \\
\hline 9 & Salahddin & 36.38 & 44.20 & 1088 & $0.55^{4}$ & $0.17^{1}$ & 2027.142 & 18.11 & 645.63 & 1499.26 \\
\hline 10 & Bashur & 36.37 & 44.37 & 977 & $0.55^{4}$ & $0.17^{1}$ & 1766.900 & 18.11 & 645.63 & 1497.10 \\
\hline 11 & Mosul & 36.31 & 43.11 & 223 & $0.54^{4}$ & $0.15^{1}$ & 668.228 & 20.61 & 586.75 & 1646.54 \\
\hline 12 & Erbil & 36.15 & 44.00 & 1088 & $0.79^{5}$ & $0.29^{3}$ & 3634.029 & 20.17 & 571.68 & 1664.42 \\
\hline \multirow[t]{2}{*}{13} & Makhmoor & 35.75 & 43.60 & 306 & $0.31^{3}$ & $0.07^{2}$ & 3634.029 & 21.26 & 360.79 & 1567.47 \\
\hline & Basin & - & - & - & $0.76^{5}$ & $0.25^{3}$ & $42,031.8$ & 14.85 & 727.12 & 1348.48 \\
\hline
\end{tabular}

a Latitude;

b Longitue;

c Altitude;

d Sub-area;

e Mean air temperature;

${ }^{f}$ Precipitation; and

g Potential evapotranspiration

${ }^{1}$ Hyper-arid $\left(\mathrm{RDI}_{\alpha 12} \leq 0.03\right.$;

${ }^{2}$ Arid $\left(0.03<\mathrm{RDI}_{\alpha 12}<0.2\right)$;

${ }^{3}$ Semi-arid $\left(0.2<\mathrm{RDI}_{\alpha 12}<0.5\right)$;

${ }^{4}$ Dry sub-humid $\left(0.5<\mathrm{RDI}_{\alpha 12}<0.65\right)$; and

${ }^{5}$ Humid $\left(0.65 \leq \mathrm{RDI}_{\alpha 12}\right)$

approximately $42,032 \mathrm{~km}^{2}$ with an elevation varying from $180 \mathrm{~m}$ above sea level (masl) to 4000 masl. Due to water erosion, the basin is filled with sandstone, gravel and conglomerate.

The UZR passes different ecological and climatic areas. The mean and the peak discharge of the river are 419 and $1320 \mathrm{~m}^{3} / \mathrm{s}$, respectively. Annual precipitation ranges between 350 and $1000 \mathrm{~mm}$ (UN-ESCWA 2013). In general, most of the UZRB precipitation occurs in winter and spring. The distribution of annual precipitation is approximately as follows: 48.9, 37.5, 12.9 and $0.7 \%$ in winter, spring, autumn and summer, respectively. The UZRB flow regime shows considerable seasonal flow variations with a maximum discharge happening in May and low seasonal flow between July and December (UN-ESCWA 2013). The basin comprises many springs that are the main sources for irrigation proposes.

\subsection{Data Availability, Collection and Analysis Techniques}

The following climate data were gathered for this research purpose; daily precipitation amount and maximum and minimum air temperature from thirteen meteorological stations for the 


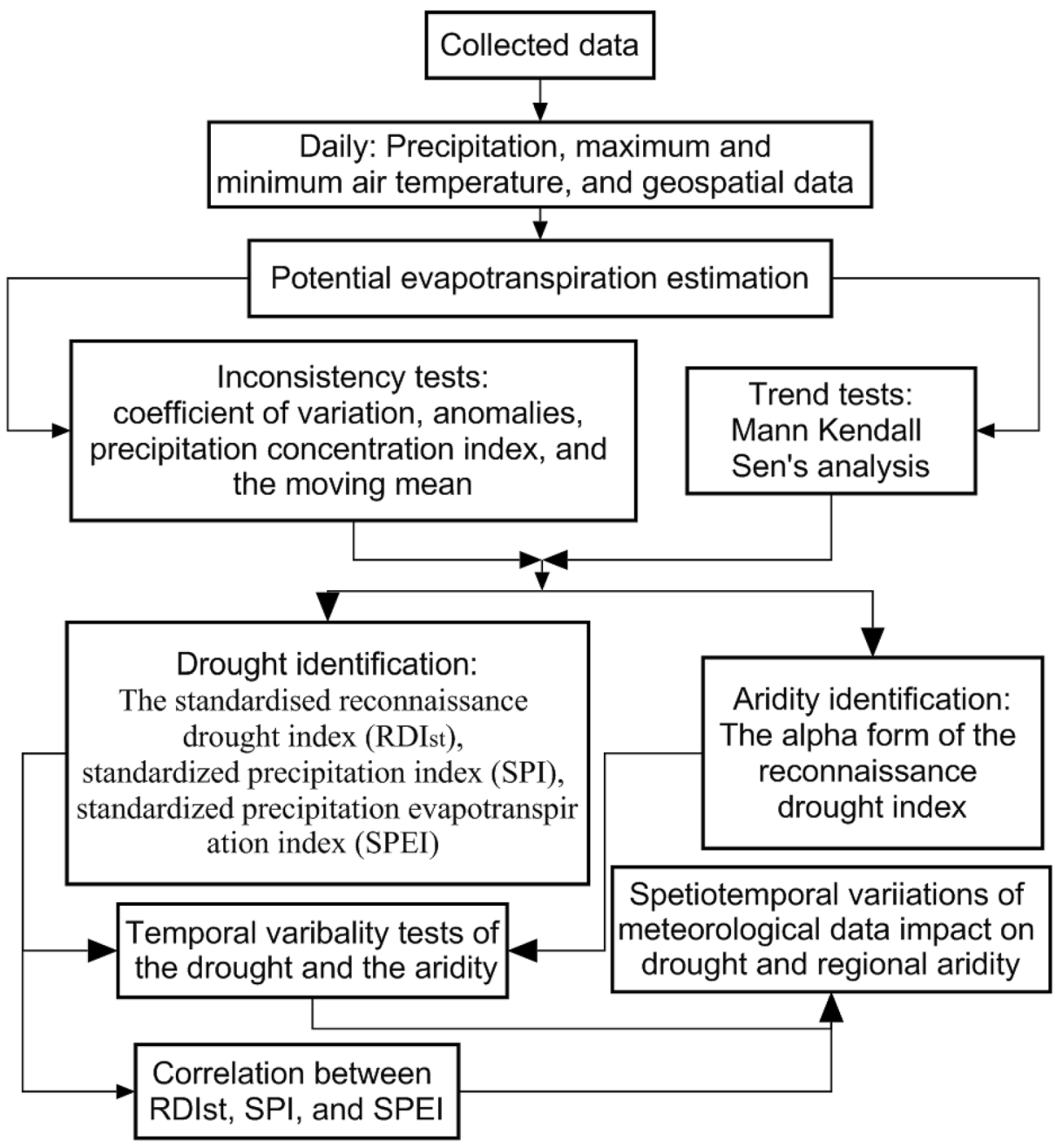

Fig. 2 Proposed methodology to assess the impact of long-term variations and distributions of meteorological data concerning regional drought and aridity

period from 1979 to 2013. The stations are spread within and outside of the UZRB with altitudes varying from 223 to 1980 masl. (Table 1 and Fig. 1). The data have been obtained from the Ministry of Agriculture and Water Resources (Kurdistan province, Iraq). The shape files of the Iraqi borders and UZRB have been obtained from the Global Administrative Areas (GADM 2012) and the Global and Land Cover Facility (GLCF 2015) databases, respectively.

For the projections of weather stations, shaping Thiessen network, and the delineations of the river and the basin, ArcGIS 10.4.1 has been used. XLSTAT, which isa user-friendly statistical software for data analysis add-in for Microsoft Excel, has been used for data analyses.

The standardised reconnaissance drought index $\left(\mathrm{RDI}_{\mathrm{st}}\right)$, standardized precipitation index (SPI), standardized precipitation evapotranspiration index (SPEI) and the alpha form of the standardised reconnaissance drought index $\left(\mathrm{RDI}_{\alpha}\right)$ were used for analyzing drought severity and regional aridity using precipitation and potential evapotranspiration. To estimate the 
potential evapotranspiration, RDI and SPI, the Drought Indices Calculator (DrinC1.5.73) (http://drinc.ewra.net/index_d.html) software has been applied (DrinC, 2018).

The Hargreaves method has been applied for the potential evapotranspiration estimation. Mohammed and Scholz (2016) stated that the Hargreaves method can be considered as the main tool to estimate potential evapotranspiration for many climatic conditions including arid and semi-arid climate as a result of its suitability for climate change research, which is supported by many research in water resources studies such as Vangelis et al. (2013) and Tigkas et al. (2012). Moreover, Mohammed and Scholz (2016) proved that the Hargreaves method was linked to the best findings that were similar to the full equation of the Food and Agriculture Organization Penman-Monteith Method. Additionally, Mohammed and Scholz (2016) proved that no significant impact on $\mathrm{RDI}_{\mathrm{st}}$ was detected by applying many potential evapotranspiration methodologies including the Hargreaves method at different elevations for a range of climate conditions. The SPEI has been estimated using the SPEI-package, which includes a set of functions for computing potential evapotranspiration and several widely used drought indices including SPEI.

To test meteorological data, many methods have been suggested (Duhan and Pandey 2013; Asfaw et al. 2018), which are generally classified into variability and trend analysis. The former set of tests applies the coefficient of variation $\left(\mathrm{C}_{\mathrm{V}}\right)$, anomalies (proportional departure from the average), precipitation concentration index (PCI) and the moving mean. However, the latter is normally performed by nonparametric and parametric analysis for regular climatic data (Duhan and Pandey 2013). The parametric analysis is a simple method, but requires climatic parameters to be normally distributed. Nevertheless, the non-parametric analysis does not assume any specific data distribution (Tabari and Taalaee, 2011).

The variability of precipitation and air temperature has been estimated using $\mathrm{C}_{\mathrm{V}}$, the standardized precipitation anomaly and PCI. The $\mathrm{CV}$ has been considered to assess the inconsistency of precipitation. A large value of $\mathrm{C}_{\mathrm{V}}$ indicates large variability and vice versa. The coefficient is calculated by using Eq. (1).

$$
\mathrm{C}_{\mathrm{V}}=\frac{\sigma}{\mu} \times 100
$$

where $C_{V}$ represents the coefficient of variation; $\sigma$ is the standard deviation; and $\mu$ indicates the average of precipitation. Based on $\mathrm{C}_{\mathrm{V}}$ values, the degree of variability of precipitation can be classified in to less $\left(C_{V}<20\right)$, moderate $\left(20 \leq C_{V} \leq 30\right)$ and high $\left(\mathrm{C}_{\mathrm{V}}>30\right)$ according to Asfaw et al. (2018). To investigate the variability of precipitation at annual and seasonal scales, PCI is used. PCI $_{\text {annual }}$ can be obtained from Eq. (2) (Asfaw et al. 2018).

$$
\mathrm{PCI}_{\text {annual }}=\frac{\sum_{\mathrm{i}=1}^{12} \mathrm{P}_{\mathrm{i}}^{2}}{\left(\sum_{\mathrm{i}=1}^{12} \mathrm{P}_{\mathrm{i}}\right)^{2}} \times 100
$$

where $\mathrm{P}_{\mathrm{i}}$ is the precipitation amount of the $\mathrm{i}^{\text {th }}$ month.

The PCI can be classified into low (uniform monthly distribution), moderate and very high precipitation concentrations. The respective ranges of PCI are as follows: $\mathrm{PCI}<10,11<\mathrm{PCI}<$ $15,16<\mathrm{PCI}<20$, and PCI $>21$, respectively. Furthermore, standardized anomalies of precipitation have been computed to study trend characteristics, enable the definition of dry and wet 
years in the measurements and to evaluate drought severity and occurrence (Asfaw et al. 2018) as represented by Eq. (3).

$$
\mathrm{Z}=\frac{\mathrm{X}_{\mathrm{i}}-\overline{\mathrm{X}_{\mathrm{i}}}}{\mathrm{s}}
$$

where $\mathrm{Z}$ represents the standardized precipitation anomaly; $\mathrm{X}_{\mathrm{i}}$ is the annual precipitation of a specific year; $\bar{X}_{\mathrm{i}}$ indicates the long-term average annual precipitation over a period of measurements; and s represents the standard deviation of yearly precipitation over a period of measurements.

The classes of drought severity are extreme, severe, moderate and no drought with the corresponding ranges $\mathrm{Z}>-0.84, \mathrm{Z}<-1.65,-1.28>\mathrm{Z}>-1.65$, and $-0.84>\mathrm{Z}>$ -1.28 , respectively. The non-parametric Mann-Kendall (M-K) test was used to identify, if there is a monotonic descending or increasing trend in the climatic time series. A monotonic increasing (descending) trend shows that the variable constantly raises (declines) during the time-period, though the trend may or may not be linear. Tabari and Taalaee (2011) and Robaa and AL-Barazanji (2013) published more details about the M-K test. Pettitt's, Standard Normal Homogeneity (SNHT), Buishand's test and von Neumann's test were applied to check the homogeneity of the climatic indices (Zahumenský, 2004). RDI, SPI and SPEI were applied to study the temporal variation of meteorological drought and aridity.

\subsection{Meteorological Drought}

\subsubsection{Reconnaissance Drought Index}

The RDI may be expressed in terms of the standardised $\left(\mathrm{RDI}_{\mathrm{st}}\right)$, normalised $\left(\mathrm{RDI}_{\mathrm{n}}\right)$ and initial $\left(\mathrm{RDI}_{\alpha \mathrm{k}}\right)$. In general, the standardised form is used to evaluate the severity of drought and the initial form is used as an aridity index. The aridity index is mainly based on the accumulated values of precipitation and potential evapotranspiration (Vangelis et al. 2013). Online Resource 1.1 involved the theoretical background of the RDI index.

A positive $\mathrm{RDI}_{\mathrm{st}}$ number represents a wet period. In contrast, a negative one is symptomatic of a dry period compared to the normal environment of the corresponding research area. The drought severity rises when the $\mathrm{RDI}_{\mathrm{st}}$ magnitude becomes minimal. Drought severity may be classified as mild $\left(-0.5<\mathrm{RDI}_{\mathrm{st}}<-1.0\right)$, moderate $\left(-1.0<\mathrm{RDI}_{\mathrm{st}}<-1.5\right)$, severe $\left(-1.5<\mathrm{RDI}_{\mathrm{st}}\right.$ $<-2.0)$ and extreme $\left(\mathrm{RDI}_{\mathrm{st}}<-2.0\right)$ classes (Tigkas et al. 2012; Vangelis et al. 2013).

\subsubsection{Standardised Precipitation Index}

The SPI can identify and monitor droughs. The evaluation of SPI at a certain location is based on a series of accumulated precipitation for a different monthly time scale such as 1, 3, 6, 9 and 12 months. The precipitation series is fitted to a probability distribution that is subsequently transformed to a normal distribution. It follows that the average SPI for the target location and the chosen period is zero. Negative numbers of SPI specify less than median precipitation, whereas positive SPI values are indicative of greater than median precipitation. The gamma distribution fits climatological precipitation time series well (Vangelis et al. 2013). 


\subsubsection{Standardized Precipitation Evapotranspiration Index}

The standardised precipitation evapotranspiration index (SPEI) is a simple multi-scalar meteorological drought index that links values of precipitation and temperature with each other. SPEI is depended on the climatic water balance (precipitation-potential evapotranspiration) for a monthly time scale. The values are aggregated at several time scales and changed to standard deviations with respect to average values. For more details regarding SPI, see Online Resources 1.2.

\section{Results and Discussion}

\subsection{Analysis of Climate Data}

To identify the long-term temporal trends in the annual key meteorological variables, this research uses the M-K and the Sen's tests. Table 2 lists the statistical analysis of the meteorological parameters representing the M-K and Sen's tests for the decadal changes concerning UZRB.

The time series of the mean temperature indicates that the non-significant trends are placed in the Iraqi part of the basin, while the stations that are located outside the Iraqi borders, show significantly $(p<0.05)$ negative trends. Temporally, the basin experienced increasing trends in mean temperature with an average value of $0.1^{\circ} \mathrm{C} /$ decade (Fig. 3a). The average annual basin temperature was $14.85^{\circ} \mathrm{C}$. The maximum mean temperature $\left(17.23^{\circ} \mathrm{C}\right)$ for $2009 / 2010$ and the corresponding minimum $\left(12.55^{\circ} \mathrm{C}\right)$ was observed during $1991 / 1992$. A deteriorating precipitation trend (Fig. 3b) had an average reduction of $137.1 \mathrm{~mm}$. The annual precipitation is around $727.12 \mathrm{~mm}$. The maximum precipitation (1067.20 mm) was observed for 1979/1980, whereas the equivalent minimum $(316.00 \mathrm{~mm}$ ) was assigned to 1999/2000.

As depicted in Table 3, December, January, February and March are the main rainfall months in the UZRB, which contributes to about $60.91 \%$ of the total precipitation (where almost $15 \%$ gains from each month), which evidently exposed the occurrence of high PCI. The non-rainy months, which contributed to $1.38 \%$ of the total, are July, August and September. There was a high inter-annual variability during the summer months (July, August and September) compared to winter (December, January, February and March) precipitation.

A significant $(p<0.05)$ rising trend for the potential evapotranspiration concerning the whole UZRB during the last half-century has been noticed (Fig. 3c and Table 2). The decadal increase in potential evapotranspiration rate was $27.10 \mathrm{~mm}$. With a mean amount of approximately $1348.48 \mathrm{~mm}$, the estimated potential evapotranspiration for varied from $1222.10 \mathrm{~mm}$ in $1982 / 1983$ to $1429.132 \mathrm{~mm}$ in $1998 / 1999$ (Fig. 3c). The research outputs show that the semi-arid environment, as illustrated through the example basin, is becoming hotter and drier as a result of climate variability during the previous three decades. For example, the annual precipitation declined and the annual average temperature rose (Table 2).

Figures $3 \mathrm{~d}-\mathrm{f}$ display the spatial distribution of the long-term average values of the meteorological parameters. Each box-whisker plot represents a meteorological variable for a certain station over UZRB, which ranged from the upstream to the downstream part of the basin. Despite that there are no coherent change trends among various stations, there are general increasing and decreasing trends in both mean temperature and potential 
Table 2 Statistical properties of the meteorological variables after applying a non-parametric test for the decadal change

\begin{tabular}{|c|c|c|c|c|c|c|c|c|c|c|}
\hline \multicolumn{2}{|c|}{ Station } & \multicolumn{3}{|c|}{ Mean air temperature $\left({ }^{\circ} \mathrm{C}\right)$} & \multicolumn{3}{|c|}{ Precipitation (mm) } & \multicolumn{3}{|c|}{$\begin{array}{l}\text { Potential } \\
\text { evapotranspiration (mm) }\end{array}$} \\
\hline No. & ID & $\mathrm{M}-\mathrm{K}^{\mathrm{a}}$ & $p$ value & $\mathrm{S}^{\mathrm{b}}$ & $\mathrm{M}-\mathrm{K}^{\mathrm{a}}$ & $p$ value & $\mathrm{S}^{\mathrm{b}}$ & $\mathrm{M}-\mathrm{K}^{\mathrm{a}}$ & $p$ value & $\mathrm{S}^{\mathrm{b}}$ \\
\hline 1 & Razi & $-0.356^{*}$ & $<0.05$ & -0.053 & $-0.311^{*}$ & $<0.05$ & -9.898 & 0.052 & 0.653 & 0.348 \\
\hline 2 & Koozerash & $-0.368^{*}$ & $<0.05$ & -0.047 & $-0.343^{*}$ & $<0.05$ & -13.903 & 0.059 & 0.614 & 0.295 \\
\hline 3 & Ravand Urmia & -0.149 & 0.207 & -0.016 & $-0.342^{*}$ & $<0.05$ & -10.417 & $0.256^{*}$ & $<0.05$ & 1.386 \\
\hline 4 & Mirbad Azarbayjan & $-0.083^{*}$ & 0.490 & -0.009 & $-0.543^{*}$ & $<0.05$ & -23.798 & 0.221 & 0.058 & 2.096 \\
\hline 5 & Soran & 0.213 & 0.070 & 0.017 & $-0.492^{*}$ & $<0.05$ & -17.752 & $0.475 *$ & $<0.05$ & 3.766 \\
\hline 6 & Duhook & $0.444^{*}$ & $<0.05$ & 0.045 & $-0.444^{*}$ & $<0.05$ & -17.172 & $0.634^{*}$ & $<0.05$ & 4.339 \\
\hline 7 & Aqra & 0.216 & 0.066 & 0.036 & $-0.444^{*}$ & $<0.05$ & -17.172 & $0.399^{*}$ & $<0.05$ & 2.594 \\
\hline 8 & Piranshahr & 0.152 & 0.197 & 0.015 & $-0.530^{*}$ & $<0.05$ & -25.88 & $0.519^{*}$ & $<0.05$ & 3.043 \\
\hline 9 & Salahddin & 0.175 & 0.139 & 0.025 & -0.225 & 0.055 & -9.567 & $0.535^{*}$ & $<0.05$ & 3.471 \\
\hline 10 & Bashur & 0.175 & 0.139 & 0.025 & -0.225 & 0.055 & -9.567 & $0.526^{*}$ & $<0.05$ & 2.961 \\
\hline 11 & Mosul & 0.286 & $<0.05$ & 0.027 & $-0.629^{*}$ & $<0.05$ & -18.895 & $0.456^{*}$ & $<0.05$ & 2.630 \\
\hline 12 & Erbeel & 0.171 & 0.146 & 0.020 & $-0.451^{*}$ & $<0.05$ & -13.776 & $0.491^{*}$ & $<0.05$ & 3.134 \\
\hline 13 & Makhmoor & 0.184 & 0.118 & 0.019 & $-0.537^{*}$ & $<0.05$ & -10.276 & $0.367^{*}$ & $<0.05$ & 0.966 \\
\hline
\end{tabular}

Negative (-) and positive values indicate decreasing and increasing trends, respectively;

${ }^{\text {a } M a n n-K e n d a l l ~ n o n-p a r a m e t r i c ~ t e s t ~}$

b Sen's slope

*Trend is significant at the 0.05 level (2-tailed);
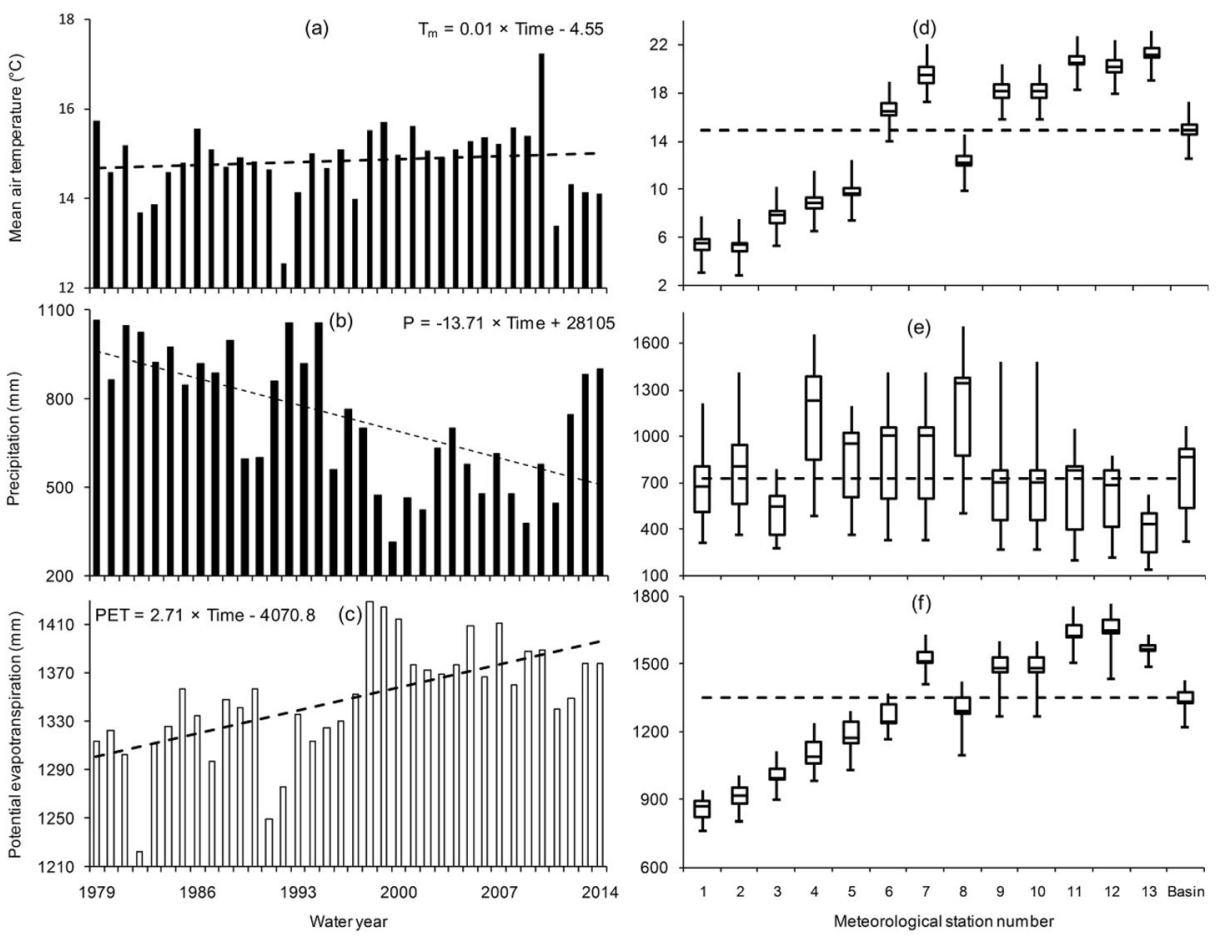

Fig. 3 Temporal variations and box plots, respectively, representing spatial variations of the key meteorological parameters: $\mathbf{a}$ and $\mathbf{d}$ mean air temperature $\left(\mathrm{T}_{\mathrm{m}}\right) ; \mathbf{b}$ and $\mathbf{e}$ precipitation $(\mathrm{P})$; and $\mathbf{c}$ and $\mathbf{f}$ potential evapotraspiration (PET) for the Upper Zab River Basin during the time-period between 1979 and 2014 
Table 3 Descriptive statistics and Mann-Kendall (M-K) trend analysis of the Upper Zab River Basin precipitation during the time-period between 1979 and 2014

\begin{tabular}{|c|c|c|c|c|c|c|c|c|c|}
\hline Month & $\operatorname{Min}^{\mathrm{a}}$ & $\operatorname{Max}^{\mathrm{b}}$ & Mean $^{c}$ & $\mathrm{SD}^{\mathrm{d}}$ & $\%$ & $\mathrm{C}_{\mathrm{V}}^{\mathrm{e}}(\%)$ & $M-K^{f}$ & $p$-vaue & Sen's slope \\
\hline Oct & 1.01 & 111.26 & 34.09 & 29.25 & 5.17 & 85.82 & $-0.241^{*}$ & $<0.05$ & -0.896 \\
\hline Nov & 0.00 & 196.75 & 77.99 & 55.55 & 11.82 & 71.23 & $-0.263^{*}$ & $<0.05$ & -1.998 \\
\hline Dec & 13.52 & 239.10 & 92.44 & 52.95 & 14.01 & 57.28 & -0.137 & 0.247 & -1.194 \\
\hline Jan & 17.93 & 327.21 & 103.16 & 55.29 & 15.63 & 53.59 & 0.063 & 0.595 & 0.282 \\
\hline Feb & 18.23 & 215.06 & 101.74 & 45.55 & 15.42 & 44.77 & -0.222 & 0.058 & -1.463 \\
\hline March & 30.47 & 222.36 & 104.54 & 48.08 & 15.84 & 45.99 & -0.143 & 0.225 & -1.322 \\
\hline April & 5.38 & 178.34 & 81.21 & 42.10 & 12.31 & 51.85 & $-0.333^{*}$ & $<0.05$ & -1.546 \\
\hline May & 7.44 & 164.75 & 45.45 & 34.50 & 6.89 & 75.90 & -0.146 & 0.215 & -0.416 \\
\hline Jun & 0.43 & 44.55 & 10.07 & 9.75 & 1.53 & 96.77 & -0.038 & 0.754 & -0.044 \\
\hline Jul & 0.04 & 12.69 & 3.25 & 3.04 & 0.49 & 93.62 & 0.054 & 0.653 & 0.016 \\
\hline Aug & 0.02 & 15.68 & 2.45 & 3.03 & 0.37 & 123.66 & -0.171 & 0.145 & -0.037 \\
\hline Sep & 0.00 & 18.07 & 3.42 & 4.33 & 0.52 & 126.66 & 0.016 & 0.902 & 0.002 \\
\hline
\end{tabular}

Negative (-) and positive values indicate decreasing and increasing trends, respectively;

a Minimum;

b Maximum;

c Mean;

d Standered deviation;

e Coeffecient of variation;

${ }^{\mathrm{f}}$ Mann-Kendall non-parametric test

*Correlation is significant at the 0.05 level (2-tailed).

evapotranspiration and precipitation, respectively, for the upstream to the downstream areas. The mean temperature varied between 12.55 and $17.23{ }^{\circ} \mathrm{C}$.

The PCI (Table 4) shows the occurrence of moderate to very high rainfall occurrences. To get a precise evaluation of the spatial distribution of precipitation, the Thiessen network has been applied. In this study, the Thiessen network was formed to assess the area of each station polygon $\left(\mathrm{a}_{\mathrm{i}}\right.$ in $\left.\mathrm{km}^{2}\right)$ as shown in Table 1 . Precipitation numbers for each meteorological station were multiplied by the area of each polygon. Meteorological stations are distributed within and outside of the basin polygons (Fig. 1). The average yearly precipitation varied spatially from $360.79 \mathrm{~mm}$ at Makhmoor station, which is placed downstream of the basin, to $1107.692 \mathrm{~mm}$ at Piranshahr climate station that is located upstream within the catchment. This shows that the upstream area of UZRB, which is characterised by high elevations, had larger precipitation amounts compared to downstream areas.

\subsection{Drought and Aridity Identification, Classification and Correlation}

To assess the occurrence of drought, the study applied the SPI, RDI $\mathrm{st}_{\mathrm{st}}$ and SPEI, which are frequently applied drought indicators. However, for aridity identification, the alpha form of the $\mathrm{RDI}\left(\mathrm{RDI}_{\alpha 12}\right)$ has been considered.

Figure 4 shows the temporal anomalies of the precipitation. Figures $5 \mathrm{a}$ and $\mathrm{b}$ present the values of the meteorological drought indices calculated for the UZRB depending on data between 1979 and 2014, and the $\mathrm{RDI}_{\alpha 12}$ index for the long-term average precipitation and potential evapotranspiration, respectively. The drought indices show similar trends in identifying total numbers of drought events over the past 35 years (1979-2014). Anon-regular annual outline of dry and wet periods was recorded, estimated by the three drought indices, 
Table 4 The Spearman correlations between meteorological drought indices and the annual standardised reconnaissance drought index $\left(\mathrm{RDI}_{\mathrm{st}}\right)$, annual standardized precipitation index (SPI), annual standardised precipitation evapotranspiration index (SPEI), and annual aridity index $\left(\mathrm{RDI}_{\alpha 12}\right)$ for the thirteen meteorological stations within the Upper Zab River Basin (UZRB) and Precipitation concentration index (PCI) of UZRB for the time period between 1979 and 2014Station name

\begin{tabular}{|c|c|c|c|c|c|c|c|}
\hline \multirow[t]{3}{*}{ No. } & \multirow[t]{3}{*}{ ID } & \multicolumn{6}{|c|}{ Spearman correlation } \\
\hline & & \multicolumn{3}{|c|}{ Meteorological drought indices } & \multicolumn{3}{|c|}{$\begin{array}{l}\text { Meteorological drought indices and aridity } \\
\text { index }\end{array}$} \\
\hline & & $\begin{array}{l}\mathrm{RDI}^{\mathrm{a}}{ }_{\text {st }} \text { vis } \\
\mathrm{SPI}^{\mathrm{b}}\end{array}$ & $\begin{array}{l}\mathrm{RDI}_{\text {st }} \text { vis } \\
\mathrm{SPEI}^{\mathrm{c}}\end{array}$ & $\begin{array}{l}\text { SPI vis } \\
\text { SPEI }\end{array}$ & $\begin{array}{l}\mathrm{RDI}_{\mathrm{st}} \text { vis } \\
\mathrm{RDI}_{\alpha 12}\end{array}$ & $\begin{array}{l}\text { SPI vis } \\
\text { RDI }_{\alpha 12}\end{array}$ & $\begin{array}{l}\text { SPEI vis } \\
\text { RDI }_{\alpha 12}\end{array}$ \\
\hline 1 & Razi & 0.990 & 0.991 & 0.929 & 1.000 & 0.990 & 0.919 \\
\hline 2 & Koozerash & 0.990 & 0.908 & 0.907 & 1.000 & 0.992 & 0.908 \\
\hline 3 & Ravand Urmia & 0.994 & 0.858 & 0.847 & 1.000 & 0.994 & 0.858 \\
\hline 4 & $\begin{array}{l}\text { Mirbad } \\
\text { Azarbayjan }\end{array}$ & 0.989 & 0.923 & 0.936 & 1.000 & 0.989 & 0.923 \\
\hline 5 & Soran & 0.987 & 0.994 & 0.929 & 1.000 & 0.987 & 0.944 \\
\hline 6 & Duhook & 0.995 & 0.913 & 0.910 & 1.000 & 0.995 & 0.913 \\
\hline 7 & Aqra & 0.996 & 0.937 & 0.937 & 1.000 & 0.996 & 0.937 \\
\hline 8 & Piranshahr & 0.994 & 0.702 & 0.687 & 1.000 & 0.994 & 0.702 \\
\hline 9 & Salahddin & 0.994 & 0.955 & 0.949 & 1.000 & 0.994 & 0.955 \\
\hline 10 & Badush & 0.997 & 0.950 & 0.949 & 1.000 & 0.997 & 0.950 \\
\hline 11 & Mosul & 0.997 & 0.968 & 0.966 & 1.000 & 0.997 & 0.968 \\
\hline 12 & Erbeel & 0.839 & 0.859 & 0.926 & 1.000 & 0.839 & 0.859 \\
\hline 13 & Makhmoor & 0.996 & 0.963 & 0.962 & 1.000 & 0.996 & 0.963 \\
\hline \multirow[t]{6}{*}{ Basin } & 0.982 & 0.971 & 0.972 & 0.995 & 0.994 & 0.975 & \\
\hline & PCI & \multicolumn{4}{|c|}{ Description } & \multicolumn{2}{|c|}{ Number of years } \\
\hline & $<10$ & \multicolumn{4}{|c|}{ Low precipitation concentration (almost uniform) } & \multicolumn{2}{|c|}{4} \\
\hline & $11-15$ & \multicolumn{4}{|c|}{ Moderate concentration } & \multicolumn{2}{|l|}{12} \\
\hline & $16-20$ & \multicolumn{4}{|c|}{ High concentration } & \multicolumn{2}{|l|}{5} \\
\hline & $\geq 21$ & \multicolumn{4}{|c|}{ Very high concentration } & \multicolumn{2}{|l|}{14} \\
\hline
\end{tabular}

Note that the mean PCI for the whole studied period is 28.66

and apparent droughts on an annual basis were recorded for 5 years; particularly, during 1998/1999, 1999/2000, 2000/2001, 2007/2008 and 2008/2009 (average values of RDI st $_{\text {, SPI }}$

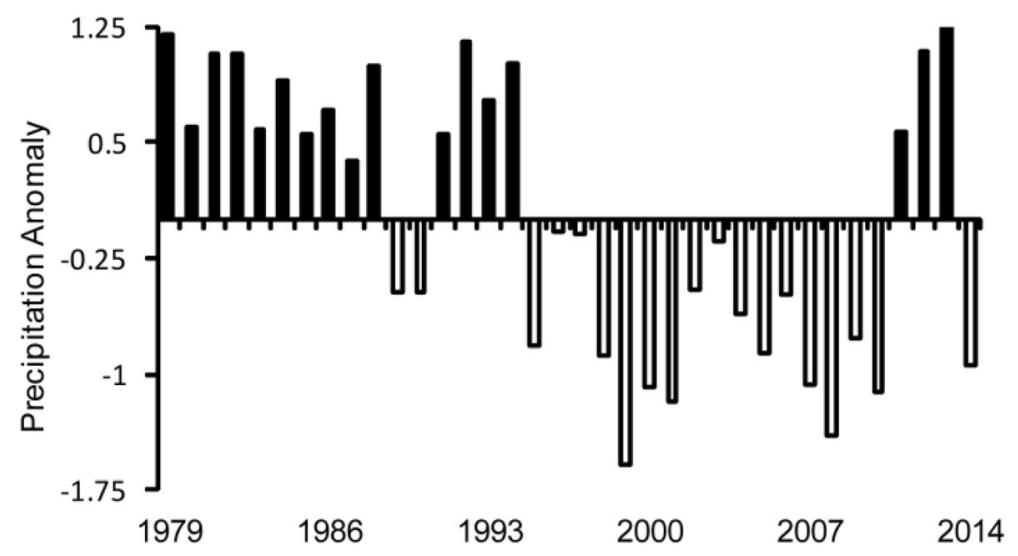

Fig. 4 The temporal aanomalies of the precipitation over the Upper Zab River Basin during the time-period between 1979 and 2014 
(a)

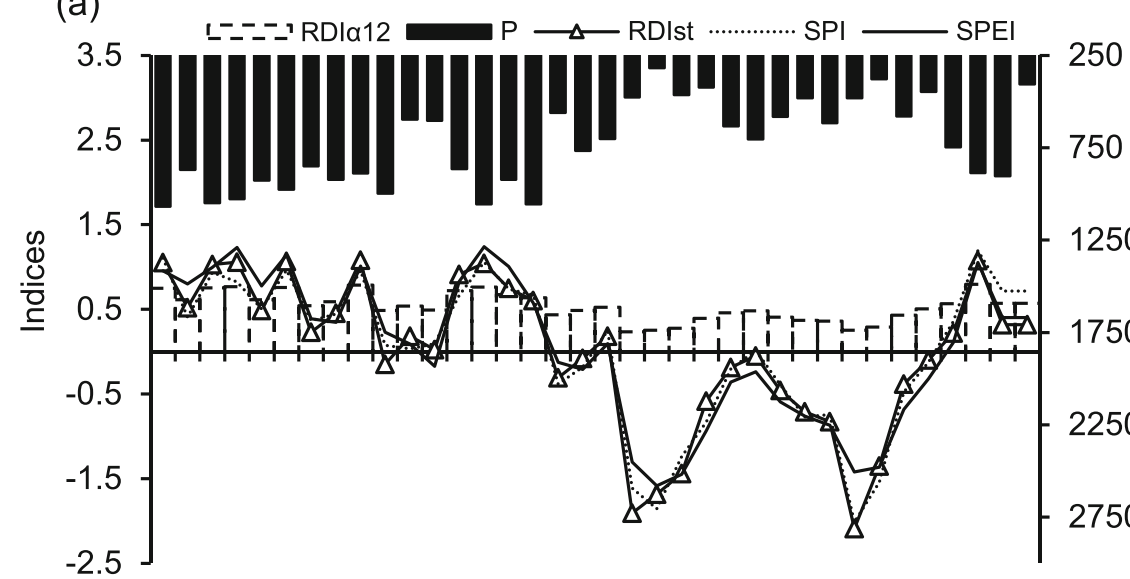

(b)

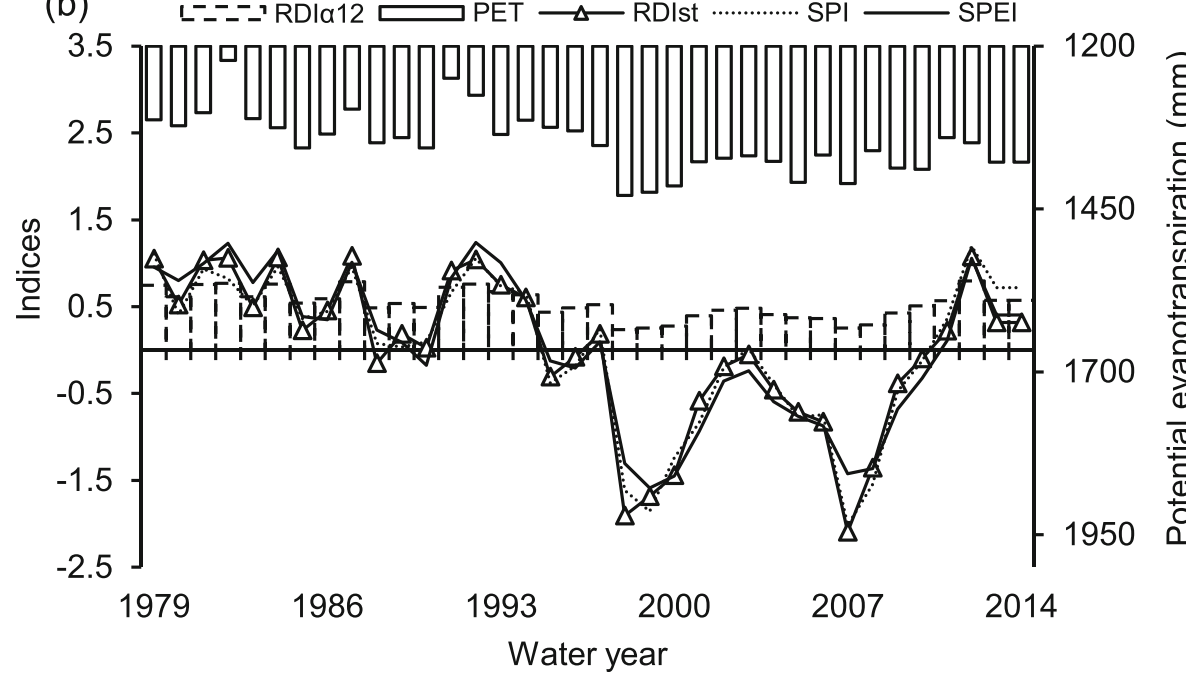

Fig. 5 The temporal distribution of the drought and aridity estimated by the standardized reconnaissance drought index $\left(\mathrm{RDI}_{\mathrm{st}}\right)$, standardized precipitation index (SPI), standardized precipitation evapotranspiration index (SPEI), and the initial reconnaissance drought index $\left(\mathrm{RDI}_{\alpha 12}\right)$ coupled with a precipitation and $\mathbf{b}$ potential evapotranspiration; variations that occurred in Upper Zab River Basin during the water years from 1979 to 2014

and SPEI are $-1.91,-1.68$ and $-1.43,-1.61,-1.86$ and -1.24 , and-1.30, -1.59 and -1.45 , respectively). Mohammed and Scholz (2017a, 2018a) and many other earlier researchers have recorded similar results.

The drought severity for UZRB has worsened considerably during the past 12 years. The drought amounts calculated from 1998 to 2011 illustrate that considerable droughts took place as the number of months with total periods of precipitation lack increased. The precipitation tendency and the long-term investigation show that the drought events and regional aridity were linked with the precipitation reduction and an increase in the potential evapotranspiration (Fig. 5a and b). Additionally, from the beginning of the year 2000, the precipitation trend shows that the area has experiencing a precipitation reduction as well as an increase in the 

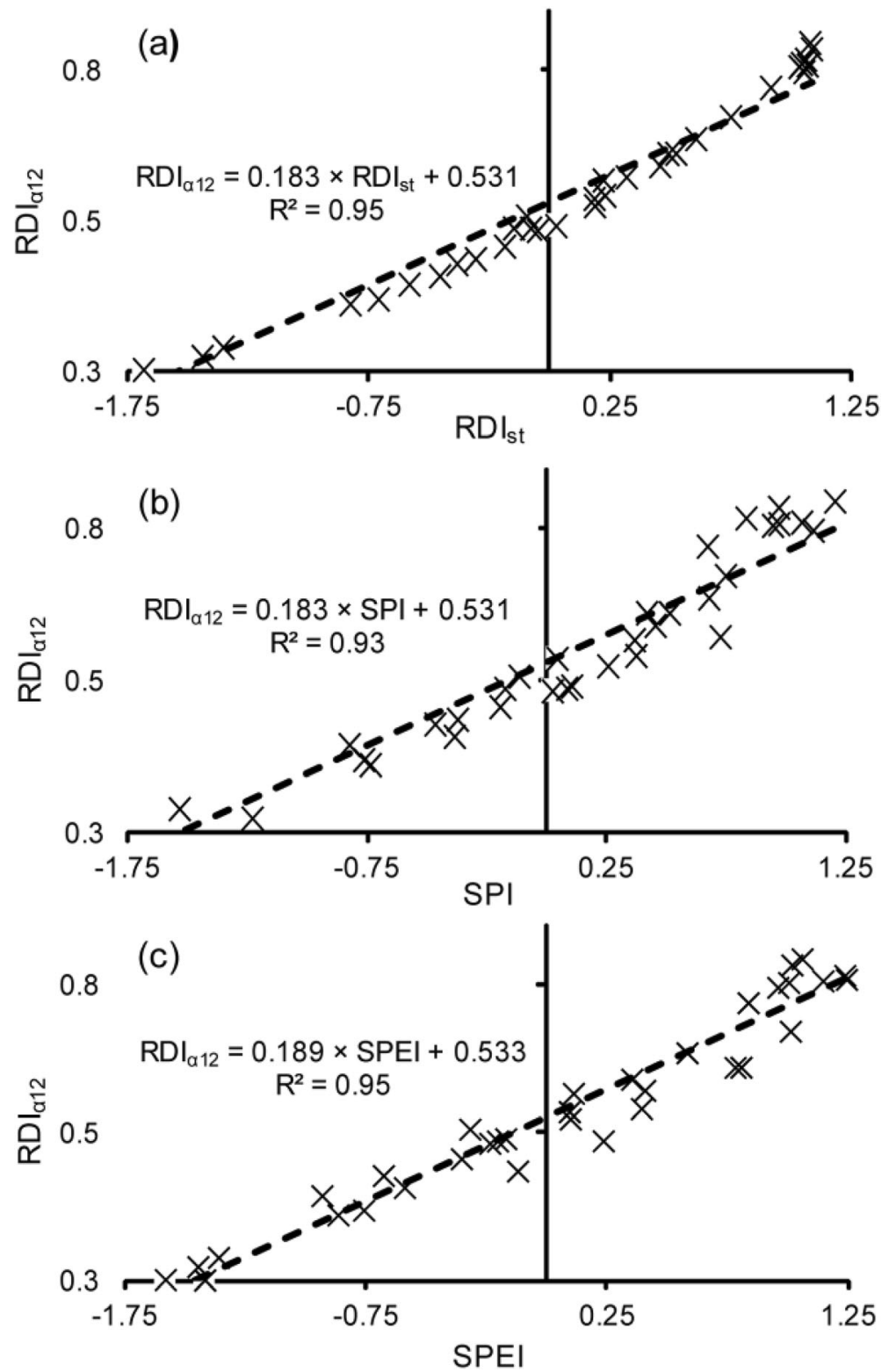

Fig. 6 Annual aridity index $\left(\mathrm{RDI}_{\alpha 12}\right)$ forecasting equations based on the a annual standardized reconnaissance drought index $\left(\mathrm{RDI}_{\mathrm{st}}\right)$; b standardized precipitation index (SPI); and c standardized precipitation evapotranspiration index (SPEI) over the Upper Zab River Basin for the time-period between 1979 and 2014

potential evapotranspiration and the drought periods. In general, as a result of precipitation decrease coupled with the potential evapotranspiration increase, particularly during the years from 2006/2007 to 2007/2008, drought and aridity have worsened (Fig. 5a and b).

Table 4 and Fig. 6 results illustrate a comparison between meteorological drought and aridity indices, which reveals that the results of the three indices were adjacent to each other. The relationship of $\mathrm{RDI}_{\mathrm{st}}$ and SPI was paramount. The association between $\mathrm{RDI}_{\mathrm{st}}$ and SPEI 
was better than between SPI and SPEI. When considering the relation between the three drought indices and $\mathrm{RDI}_{\alpha 12}$, there is a better correlation with $\mathrm{RDI}_{\mathrm{st}}$ compared to the correlation with SPI and SPEI, (Table 4 and Fig. 6). Accordingly, RDI $_{\text {st }}$ can be considered for drought identification and should therefore be chosen for additional regional drought analysis.

Figures $7 \mathrm{a}, \mathrm{c}$, e, and $\mathrm{g}$ show the long-term variations of $\mathrm{RDI}_{\mathrm{st}}$, SPI, SPEI and $\mathrm{RDI}_{\alpha 12}$. In general, the drought indices varied from about 1.08 to $-2.09,1.24$ to -2.18 , and 1.23 to -1.59 , respectively. $\mathrm{RDI}_{\alpha 12}$ values varied from about 0.24 to 0.80 across the entire basin. The indices are relatively lower before $1996 / 1997$ with mean values of $0.53,0.50,0.59$ and 0.63 , respectively. Then, they rose suddenly from $1996 / 1997$ to $2000 / 2001$. Larger RDI st $_{\text {, SPI, SPEI, and RDI }}$ 12 $_{2}$ values with means of $-1.68,-1.86,-1.59$, and 0.25 , respectively, are noticed between 1996/1997 and 2000/2001. The year 2007/2008 is considered as the driest with $\mathrm{RDI}_{\mathrm{st}}, \mathrm{SPI}, \mathrm{SPEI}$ and RDI $\mathrm{R}_{\alpha 2}$ of $-2.09,-2.01,-1.42$ and 0.24 , respectively. For the total period, the indice values increased significantly $(p<0.05)$ at a yearly rate of $-0.040,-0.035,-0.0085$ and -0.0085 , correspondingly, which indicate that the UZRB climate tended to be drier in recent years.

\subsection{Change Point Identification}

Figures $7 \mathrm{a}-\mathrm{g}$ show that due to climate variability, the annual drought and aridity trends have increased over the UZRB. Tables 5 and 6 lists the outcomes of change point likelihood for the
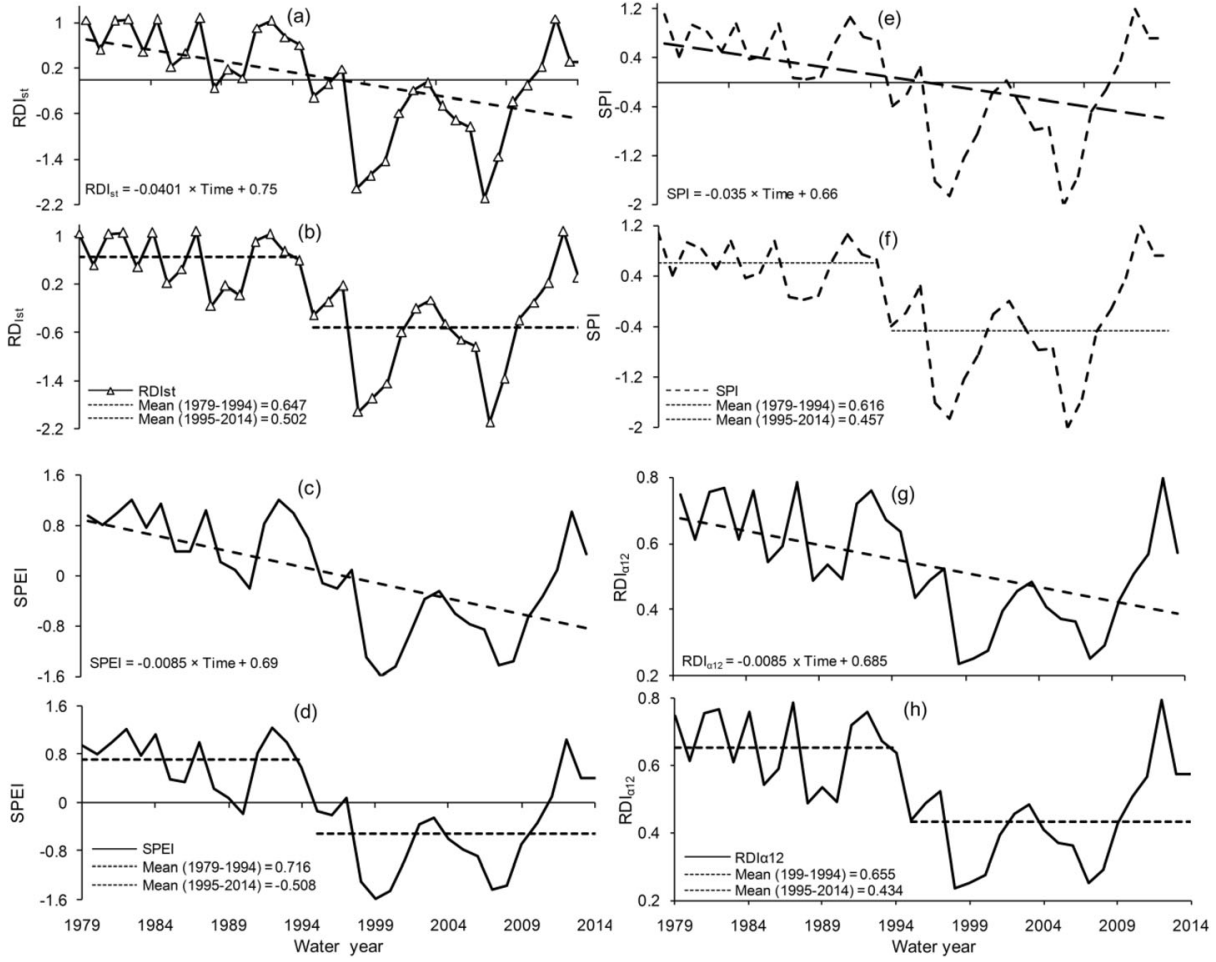

Fig. 7 a, c, e and $\mathbf{g}$ Annual values and trends of meteorological drought phenomena represented by the standardized reconnaissance drought index $\left(\mathrm{RDI}_{\mathrm{st}}\right)$, the standardized precipitation index (SPI), standardized precipitation evapotranspiration index (SPEI) and the standardized reconnaissance drought index $\left(\mathrm{RDI}_{\alpha 12}\right)$; and $\mathbf{b}, \mathbf{d}, \mathbf{f}$ and $\mathbf{h}$ Pettitt test for detecting a change in the annual values of $\mathrm{RDI}_{\mathrm{st}}, \mathrm{SPI}, \mathrm{SPEI}$, and $\mathrm{RDI}_{\alpha 12}$ for the Upper Zab River Basin for the time-period between 1979 and 2013 
Table 5 Station addresses with corresponding homogeneity test for the basin annual standardised reconnaissancedrought index $\left(\mathrm{RDI}_{\mathrm{st}}\right)$; annual standardized precipitation index (SPI), annual standardised precipitation evapotranspiration index (SPEI) and annual aridity index $\left(\mathrm{RDI}_{\alpha 12}\right)$

\begin{tabular}{|c|c|c|c|c|c|c|c|c|}
\hline \multirow[t]{2}{*}{ Index } & \multicolumn{4}{|c|}{ Statistical analysis } & \multicolumn{4}{|c|}{ homogeneity test } \\
\hline & $\operatorname{Min}^{\mathrm{a}}$ & $\operatorname{Max}^{\mathrm{b}}$ & Mean & $\mathrm{SD}^{\mathrm{c}}$ & $\begin{array}{l}1^{\mathrm{d}} \\
\mathrm{k} \text {-value }\left(5^{\mathrm{h}}\right)\end{array}$ & $\begin{array}{l}2^{\mathrm{e}} \\
\mathrm{T}_{\mathrm{o}}\left(5^{\mathrm{h}}\right)\end{array}$ & $\begin{array}{l}3^{\mathrm{f}} \\
\text { Q-value }\left(5^{\mathrm{h}}\right)\end{array}$ & $\begin{array}{l}4^{\mathrm{g}} \\
\mathrm{R} \text {-value }\left(5^{\mathrm{h}}\right)\end{array}$ \\
\hline $\mathrm{RDI}_{\mathrm{st}}$ & -2.09 & 1.08 & 0.01 & 0.89 & $256\left(\mathrm{H}_{\mathrm{a}}\right)$ & $14.94\left(\mathrm{H}_{\mathrm{a}}\right)$ & $11.69\left(\mathrm{H}_{\mathrm{a}}\right)$ & $13.86\left(\mathrm{H}_{\mathrm{a}}\right)$ \\
\hline SPI & -2.01 & 1.20 & 0.02 & 0.88 & $240\left(\mathrm{H}_{\mathrm{a}}\right)$ & $13.21\left(\mathrm{H}_{\mathrm{a}}\right)$ & $10.99\left(\mathrm{H}_{\mathrm{a}}\right)$ & $14.34\left(\mathrm{H}_{\mathrm{a}}\right)$ \\
\hline SPEI & -1.59 & 1.24 & 0.04 & 0.86 & $264\left(\mathrm{H}_{\mathrm{a}}\right)$ & $17 . .98\left(\mathrm{H}_{\mathrm{a}}\right)$ & $12.82\left(\mathrm{H}_{\mathrm{a}}\right)$ & $14.97\left(\mathrm{H}_{\mathrm{a}}\right)$ \\
\hline $\mathrm{AI}$ & 0.24 & 0.80 & 0.53 & 0.17 & $256\left(\mathrm{H}_{\mathrm{a}}\right)$ & $15.71\left(\mathrm{H}_{\mathrm{a}}\right)$ & $11.98\left(\mathrm{H}_{\mathrm{a}}\right)$ & $14.30\left(\mathrm{H}_{\mathrm{a}}\right)$ \\
\hline
\end{tabular}

The year 1994 is the change point for all indices that have been estimated by the four considered homogeneity tests. $\mathrm{H}_{\mathrm{o}}$ means that the series is homogeneous and $\mathrm{H}_{\mathrm{a}}$ indicates that the series is heterogeneous

a Minimum;

b Maximum;

c Standared deviation;

d Pettitt's test;

e Standard normal homogeneity test (SNHT);

${ }^{f}$ Buishand's test;

g Von Neumann's test;

and ${ }^{\mathrm{h}}$ Hypothesis

annual $\mathrm{RDI}_{\mathrm{st}}$, SPI, SPEI and RDI ${ }_{\alpha 12}$ values. Pettitt's, SNHT, Buishand's and von Neumann's tests were applied to check the climatic indices homogeneity level. The outcomes display that the annual climate time series were heterogeneous, indicating a significant alteration in the mean pre- and post-change point, which is specified by all tests in all studied stations to be

Table 6 The homogeneity test for the basin annual standardised reconnaissance drought index $\left(\mathrm{RDI}_{\mathrm{st}}\right)$; annual standardized precipitation index (SPI), annual standardised precipitation evapotranspiration index (SPEI) and annual aridity index $\left(\mathrm{RDI}_{\alpha 12}\right)$

\begin{tabular}{|c|c|c|c|c|c|c|c|c|}
\hline \multirow[t]{2}{*}{ Index } & \multicolumn{4}{|c|}{ Statistical analysis } & \multicolumn{4}{|c|}{ homogeneity test } \\
\hline & $\operatorname{Min}^{\mathrm{a}}$ & $\operatorname{Max}^{\mathrm{b}}$ & Mean & $\mathrm{SD}^{\mathrm{c}}$ & $\begin{array}{l}1^{\mathrm{d}} \\
\mathrm{k} \text {-value }\left(5^{\mathrm{h}}\right)\end{array}$ & $\begin{array}{l}2^{\mathrm{e}} \\
\mathrm{T}_{\mathrm{o}}\left(5^{\mathrm{h}}\right)\end{array}$ & $\begin{array}{l}3^{\mathrm{f}} \\
\text { Q-value }\left(5^{\mathrm{h}}\right)\end{array}$ & $\begin{array}{l}4^{\mathrm{g}} \\
\mathrm{R} \text {-value }\left(5^{\mathrm{h}}\right)\end{array}$ \\
\hline $\mathrm{RDI}_{\mathrm{st}}$ & -2.09 & 1.08 & 0.01 & 0.89 & $256\left(\mathrm{H}_{\mathrm{a}}\right)$ & $14.94\left(\mathrm{H}_{\mathrm{a}}\right)$ & $11.69\left(\mathrm{H}_{\mathrm{a}}\right)$ & $13.86\left(\mathrm{H}_{\mathrm{a}}\right)$ \\
\hline SPI & -2.01 & 1.20 & 0.02 & 0.88 & $240\left(\mathrm{H}_{\mathrm{a}}\right)$ & $13.21\left(\mathrm{H}_{\mathrm{a}}\right)$ & $10.99\left(\mathrm{H}_{\mathrm{a}}\right)$ & $14.34\left(\mathrm{H}_{\mathrm{a}}\right)$ \\
\hline SPEI & -1.59 & 1.24 & 0.04 & 0.86 & $264\left(\mathrm{H}_{\mathrm{a}}\right)$ & $17 . .98\left(\mathrm{H}_{\mathrm{a}}\right)$ & $12.82\left(\mathrm{H}_{\mathrm{a}}\right)$ & $14.97\left(\mathrm{H}_{\mathrm{a}}\right)$ \\
\hline $\mathrm{RDI}_{\alpha 12}$ & 0.24 & 0.80 & 0.53 & 0.17 & $256\left(\mathrm{H}_{\mathrm{a}}\right)$ & $15.71\left(\mathrm{H}_{\mathrm{a}}\right)$ & $11.98\left(\mathrm{H}_{\mathrm{a}}\right)$ & $14.30\left(\mathrm{H}_{\mathrm{a}}\right)$ \\
\hline
\end{tabular}

The year 1994 is the change point for all indices that have been estimated by the four considered homogeneity tests. $\mathrm{H}_{\mathrm{o}}$ means that the series is homogeneous and $\mathrm{H}_{\mathrm{a}}$ indicates that the series is heterogeneous

a Minimum;

b Maximum;

c Standared deviation;

d Pettitt's test;

e Standard normal homogeneity test (SNHT);

f Buishand's test;

g Von Neumann's test; and

${ }^{\mathrm{h}}$ Hypothesis 
1994/1995. The SNHT analysis identified the change point at the start and end of a series. However, Buishand's and Pettitt's analyses are sensitive to find the alterations in a series center.

Figures $7 \mathrm{~b}-\mathrm{h}$ explain the change point years for the drought and aridity time series using the Pettitt method. The figures confirm that there is an evident change in the average of the indicator time series pre- and post-change point (1994). Accordingly, 1994/1995 is seen as a change point for the assessed time series, which reflects the impact of climate variability and anthropogenic interventions on the basin climate.

\section{Conclusions}

There was sufficient evidence for defining climate data trend alterations in the assessed region. The findings indicate that there are declining and rising trends in yearly mean temperature. However, most of them were not statistically significant $(p>0.05)$. A significant $(p<0.05)$ decreasing trend in precipitation was noted. Increasing trends in the potential evapotranspiration were computed. However, most of these trends were not significant $(p>0.05)$. An assessment of meteorological drought trends showed that droughts have surged.

Despite that there are no coherent change trends in the spatial distribution of the climate data, there are general increasing trends in average temperature and potential evapotranspiration as well as decreasing trends in precipitation from the upstream to the downstream areas of the basin. The average precipitation concentration indicates high precipitation concentrations. The precipitation anomaly witnessed for the occurrence of the trend being lower than the longterm mean becomes evident mainly after 1994/1995.

The long-term analysis of climate data reveals that the number of dry years has temporally risen and the basin has encountered succeeding years of drought, particularly after 1994/1995. Humid and dry sub-humid sub-basins are likely to become arid and hyper-arid due to climate variability. There is a strong relationship between drought, aridity and climate variability.

The potential differences and similarities among $\mathrm{RDI}_{\mathrm{st}}$, SPI and SPEI indices were investigated by a comprehensive comparability analysis. Observations indicated that there is a better correlation with $\mathrm{RDI}_{\mathrm{st}}$ compared to the one with SPI and SPEI.

The drought and regional aridity variations and the role of climate variability were investigated applying linear regression and homogeneity tests. The annual $\mathrm{RDI}_{\mathrm{st}}$, SPI, SPEI and $\mathrm{RDI}_{\alpha 12}$ values increased significantly $(p<0.05)$ at the annual rate of $-0.0401,-0.035$, -0.0085 and -0.0085 , respectively, and a remarkable alteration occurred in 1994 . The increase in drought and the aridity indicated that during the last three decades UZRB became drier, which is affecting the regional water resources availability. Pettitt's, SNHT, Buishand's and von Neumann's test results proved that there is an evident variation in the mean of the drought and aridity between the pre- and post-change point (1994). Consequently, 1994/1995 can be considered as a reflection for the potential impact of climate variability.

Finally, the results indicated that using only trend analysis, whether it is parametric or nonparametric, cannot be considered sufficient enough for climate variability evaluation. Adding a homogeneity test to the analysis would provide a clear picture concerning the long-term variations of the climatic variables, particularly drought and aridity.

Acknowledgements The authors acknowledge the support of their respective institutions. This research did not receive any specific grant from funding agencies in the public, commercial or not-for-profit sectors. 
Funding Information Open access funding provided by Lund University.

\section{Compliance with Ethical Standards}

\section{Conflict of Interest None.}

Open Access This article is distributed under the terms of the Creative Commons Attribution 4.0 International License (http://creativecommons.org/licenses/by/4.0/), which permits unrestricted use, distribution, and reproduction in any medium, provided you give appropriate credit to the original author(s) and the source, provide a link to the Creative Commons license, and indicate if changes were made.

\section{References}

Ahmad I, Zhang F, Tayyab M, Anjum MN, Zaman M, Liu J, Farid HU, Saddique Q (2018) Spatiotemporal analysis of precipitation variability in annual, seasonal and extreme values over upper Indus River basin. Atmos Res 213:346-360. https://doi.org/10.1016/j.atmosres.2018.06.019

Ahmed K, Shahid S, Wang X, Nawaz N, Khan N (2019) Spatiotemporal changes in aridity of Pakistan during 1901-2016. Hydrol Earth Syst Sci 23(7):3081-3096

Asfaw A, Simane B, Hassen A, Bantider A (2018) Variability and time series trend analysis of rainfall and temperature in north Central Ethiopia: a case study in Woleka sub-basin. Weather Clim Extremes 19:29-41. https://doi.org/10.1016/j.wace.2017.12.002

Banimahd SA, Khalili D (2013) Factors influencing Markov chains predictability characteristics, utilizing SPI, RDI, EDI and SPEI drought indices in different climatic zones. Water Resour Manag 27(11):3911-3928. https://doi.org/10.1007/s11269-013-0387-z

Beguería S, Vicente-Serrano SM, Reig F, Latorre B (2014) Standardized precipitation evapotranspiration index (SPEI) revisited: parameter fitting, evapotranspiration models, tools, datasets and drought monitoring. Int J Climatol 134(10):3001-3023. https://doi.org/10.1002/joc.3887

Cheng Q, Gao L, Chen Y, Liu M, Deng H, Chen X (2018) Temporal-spatial characteristics of drought in Guizhou Province, China, based on multiple drought indices and historical disaster records. Adv Meteorol 2018:1-22. https://doi.org/10.1155/2018/4721269

Deng Y, Gou X, Gao L, Yang M, Zhang F (2017) Spatiotemporal drought variability of the eastern Tibetan plateau during the last millennium. Clim Dyn 49(5-6):2077-2091. https://doi.org/10.1007/s00382-0163433-8

Djebou DCS (2017) Bridging drought and climate aridity. J Arid Environ 144:170-180. https://doi.org/10.1016/j. jaridenv.2017.05.002

DrinC, Drought Indices Calculator (2018) Available from http://drinc.ewra.net/index_d.html. Accessed 03 Mar 2018

Duhan D, Pandey A (2013) Statistical analysis of long term spatial and temporal trends of precipitation during 1901-2002 at Madhya Pradesh, India. Atmos Res 122:136-149. https://doi.org/10.1016/j. atmosres.2012.10.010

GADM, Global Administrative Areas Database (2012) Boundaries without limits. Available from http://www. gadm.org. Accessed 10 Mar 2018

GLCF, Global and Land Cover Facility (2015) Earth science data interface. Available from http://www.landcover. org/data/srtm. Accessed 5 Mar 2018

Hazbavi Z, Baartman JE, Nunes JP, Keesstra SD, Sadeghi SH (2018) Changeability of reliability, resilience and vulnerability indicators with respect to drought patterns. Ecol Indic 87:196-208. https://doi.org/10.1016/j. ecolind.2017.12.054

Hrnjak I, Lukić T, Gavrilov MB, Marković SB, Unkašević M, Tošić I (2014) Aridity in Vojvodina, Serbia. Theor Appl Climatol 115(1-2):323-332. https://doi.org/10.1007/s00704-013-0893-1

Khan MI, Liu D, Fu Q, Dong S, Liaqat UW, Faiz MA, Hu Y, Saddique Q (2016) Recent climate trends and drought behavioral assessment based on precipitation and temperature data series in the Songhua River basin of China. Water Resour Manag 30(13):4839-4859. https://doi.org/10.1007/s11269-016-1456-X

Koutroulis AG, Vrohidou AEK, Tsanis IK (2011) Spatiotemporal characteristics of meteorological drought for the island of Crete. J Hydrometeorol 12(2):206-226. https://doi.org/10.1175/2010JHM1252.1

Liu X, Wang S, Zhou Y, Wang F, Li W, Liu W (2015) Regionalization and spatiotemporal variation of drought in China based on standardized precipitation evapotranspiration index (1961-2013). Adv Meteorol 2015: Article ID 950262. https://doi.org/10.1155/2015/950262 
Michel D, Pandya A (2009) Troubled waters - climate change, hydropolitics, and transboundary resources. The Henry L Stimson Center, Washington DC

Mittal N, Bhave AG, Mishra A, Singh R (2016) Impact of human intervention and climate change on natural flow regime. Water Resour Manag 30(2):685-699. https://doi.org/10.1007/s11269-015-1185-6

Mohammed R and Scholz M (2016) Impact of climate variability and streamflow alteration on groundwater contribution to the base flow of the Lower Zab River (Iran and Iraq). Environ Earth Sci 75(21): 1-11

Mohammed R, Scholz M (2017a) The reconnaissance drought index: a method for detecting regional arid climatic variability and potential drought risk. J Arid Environ 144:181-191. https://doi.org/10.1016/j. jaridenv.2017.03.014

Mohammed R, Scholz M (2017b) Adaptation strategy to mitigate the impact of climate change on water resources in arid and semi-arid regions: a case study. Water Resour Manag 31(11):3557-3573. https://doi. org $/ 10.1007 / \mathrm{s} 11269-017-1685-7$

Mohammed R, Scholz M (2017c) Impact of evapotranspiration formulations at various elevations on the reconnaissance drought index. Water Resour Manag 31(1):531-538. https://doi.org/10.1007/s11269-0161546-9

Mohammed R, Scholz M (2018) Climate change and anthropogenic intervention impact on the hydrologic anomalies in a semi-arid area: lower Zab River basin, Iraq. Environ Earth Sci 77(10):357. https://doi. org/10.1007/s12665-018-7537-9

Moral FJ, Rebollo FJ, Paniagua LL, García-Martín A, Honorio F (2016) Spatial distribution and comparison of aridity indices in Extremadura, southwestern Spain. Theor Appl Climatol 126(3-4):801-814. https://doi. org/10.1007/s00704-015-1615-7

Nations Economic and Social Commission for Western Asia (UN-ESCWA), B.G.R (2013) Inventory of Shared Water Resources in Western Asia, Bundesanstalt für Geowissenschaften und Rohstoffe. http://waterinventory.org. Accessed 15 Aug 2018

Radaković MG, Tošić I, Bačević N, Mladjan D, Gavrilov MB, Marković SB (2018) The analysis of aridity in Central Serbia from 1949 to 2015. Theor Appl Climatol:1-12. https://doi.org/10.1007/s00704-017-2220-8

Robaa SM, AL-Barazanji ZJ (2013) Trends of annual mean surface air temperature over Iraq. Nat Sci 11(12): $138-145$

Tabari H, Taalaee PH (2011) Analysis of trend in temperature data in arid and semi-arid regions of Iran. Glob Planet Change 79(1-2):1-10. https://doi.org/10.1016/j.gloplacha.2011.07.008

Tabari H, Abghari H, Hosseinzadeh Talaee P (2012) Temporal trends and spatial characteristics of drought and rainfall in arid and semiarid regions of Iran. Hydrol Process 26(22):3351-3361

Tigkas D, Vangelis H, Tsakiris G (2012) Drought and climatic change impact on streamflow in small watersheds. Sci Total Environ 440:33-41. https://doi.org/10.1016/j.scitotenv.2012.08.035

Trenberth KE, Dai A, Van Der Schrier G, Jones PD, Barichivich J, Briffa KR, Sheffield J (2014) Global warming and changes in drought. Nat Clim Chang 4(1):17. https://doi.org/10.1038/NCLIMATE2067

Vangelis H, Tigkas D, Tsakiris G (2013) The effect of PET method on reconnaissance drought index (RDI) calculation. J Arid Environ 88:130-140. https://doi.org/10.1016/j.jaridenv.2012.07.020

Yue Y, Shen SH, Wang Q (2018) Trend and variability in droughts in Northeast China based on the reconnaissance drought index. Water 10(3):318. https://doi.org/10.3390/w10030318

Zahumenský I (2004) Guidelines on quality control procedures for data from automatic weather stations. World Meteorological Organization, Geneva https://www.wmo.int/pages/prog/www/IMOP/meetings/Surface/ETSTMT1 Geneva2004/Doc6.1(2).pdf

Publisher's Note Springer Nature remains neutral with regard to jurisdictional claims in published maps and institutional affiliations.

\section{Affiliations}

\section{Ruqayah Mohammed ${ }^{1,2} \cdot$ Miklas Scholz $^{2,3,4}$}

1 Civil Engineering Department, Faculty of Engineering, The University of Babylon, Hilla, Iraq 
2 Civil Engineering Research Group, School of Computing, Science and Engineering, The University of Salford, Newton Building, Peel Park Campus, Salford, Greater Manchester M5 4WT, UK

3 Division of Water Resources Engineering, Department of Building and Environmental Technology, Faculty of Engineering, Lund University, P.O. Box 118, 22100 Lund, Sweden

4 Department of Civil Engineering Science, School of Civil Engineering and the Built Environment, University of Johannesburg, Kingsway Campus, PO Box 524, Aukland Park 2006, Johannesburg, South Africa 